\title{
K-POP STRATEGY SEEN FROM THE VIEWPOINT OF CULTURAL HYBRIDITY AND THE TRADITION OF THE GWANGDAE
}

\author{
Hee-chul Sim \\ Dong-ah Institute of Media and Art \\ simba3626@naver.com
}

\author{
Soel-ah Kim \\ Konkuk University \\ soelah@gmail.com \\ Byung-min Lee \\ Konkuk University \\ yurifin@konkuk.ac.kr
}

\begin{abstract}
Hallyu (the Korean wave) is an intriguing phenomenon originating from Korea and refers to the current impact of products of South Korean popular culture (especially for music, K-pop). K-pop, a representative product of the Korean Wave, is a multi-layered formation that is composed of hybrid cultural practices and a diverse range of lived experiences. Nowadays, much social and academic attention is being paid to the reason for the success of K-pop. This study deals with how the Korean traditional gwangdae (scaramouche or clown) culture has been passed down to develop into K-pop. For this, diachronic perspectives are applied to analyze the formation and development of gwangdae culture and K-pop; and the cultural hybridity theories are used in explaining the succession of gwangdae spirit to K-pop culture. As a result, this study examines how and what kinds of changes and innovations Korean gwangdae culture has gone through to accumulate, pass down and develop the gwangdae's artistic and cultural capabilities, living up to the demands of the times, since earlier times. Thus, this study tries to understand the meaning through traditional interpretation and reflections on K-pop and also makes specific policy recommendations to accompany the analysis. In particular, we tried to present the direction of the new K-pop strategy based on the gwangdae spirit.
\end{abstract}

\section{Keywords}

Cultural Hybridity, Diachronic, Gwangdae Spirit, Hallyu, K-pop, New K-pop Gwangdae Strategy 


\section{About the Authors}

Hee-Chul Sim received his PhD in the Department of Digital Culture \& Contents at Konkuk University in Seoul. He is a professor of entertainment management and head of the K-pop Research Center in Dong-ah Institute of Media and Art in Korea.

Soel-ah Kim earned her PhD in Sciences of Information \& Communication at the University of Paris 2 Panthéon-Assas in France. She is currently Research Professor at the Research Institute of Creative Contents at Konkuk University in Seoul, Korea. Her interests include media contents, especially in the area of television and popular culture, as well as cultural policy. She has written "Social-cultural History of Korean broadcasting: from the Japanese occupation to the 1980's," and translated "A cultural history of European television 1950-2010: from public service to reality television," along with and many other articles.

Byung-Min Lee received his PhD in Geography at Seoul National University in Seoul, Korea and is currently Associate Professor of Department of Digital Culture \& Contents at Konkuk University in Korea. He has conducted many studies on the Korean Wave, Urban Regeneration through Culture, and Development of Cultural Contents Industry Policy. He recently participated in the ICCPR (International Conference on Cultural Policy Research) in Seoul as well as many other international conferences on the topic of East Asian popular culture. 


\section{INTRODUCTION}

Hallyu (Korean wave) is an intriguing phenomenon originating from Korea and refers to the current impact of products specific to South Korean popular culture (especially for music, K-pop). K-pop, the representative product of the Korean Wave, has recently gained popularity around the world, while a great deal of social and academic attention has been paid to the reason for the success of K-pop as part of Hallyu. Some studies claim that "cultural proximity" is the main reason for the success of Hallyu in Asia (Straubharr). There is another analysis based on cultural heritage theory: that since the Korean people, who traditionally, or more aptly, inherently, enjoy drinking, singing and dancing and celebrating in high spirits easily, possess a distinctive cultural and artistic DNA, and this cultural gene has long been passed down and revealed, thus leading to the global success of K-pop today (SM. Lee; P. Kim). ${ }^{1}$ Some other studies based on the cultural hybridity theory analyze Hallyu contents as the result of globalization (Iwabuchi; D. Shim) or understand this phenomenon as a glocal process or glocalization (Oh and Park).

Different from other studies trying to analyze and understand the reason for the success of Hallyu or K-pop, our study is focused on showing the connectivity from traditional gwangdae $e^{2}$ culture to K-pop by going all the way back to the pre-modern society of Korea. In other words, this study tries to find the common particularities between K-pop and traditional gwangdae culture that have existed since the Goryeo Dynasty $^{3}$ and argues that the tradition or spirit of gwangdae remains in K-pop culture. Then we analyze how this gwangdae culture has been connected to the culture of K-pop. In addition, we examine what kinds of innovations and changes Korea's modern and contemporary music and popular performance culture have gone through and how they have developed in society as a whole. Furthermore, this study deals with the future strategy and direction of K-pop based on the new gwangdae spirit.

\section{THE DIACHRONIC PERSPECTIVE OF K-POP}

This research aims to take a diachronic look at the intrinsic Korean gwangdae spirit, which has continued to be traced to K-pop. However, many scholars involved in the K-pop studies have argued with suggestion that K-pop is inherent in the Korea which we are presenting. Among the criticisms of K-pop, the most persuasive evaluations to date are those of scholars based on the theory of hybridity. 


\section{Cultural hybridity and K-pop}

Marwan M. Kraidy, a cultural scholar, defines the hybridity as "the fusion of two hitherto relatively distinct forms, styles, or identities . . which often occurs across national borders as well as across cultural boundaries" (5). Considering globalization as the process of hybridization, J. N. Pieterse defined hybridization as "the ways in which forms become separated from existing practices and recombine with new forms in new practices" (49). ${ }^{4}$ Most of the scholars who study K-pop based on hybridity theory see K-pop to be the result of a mix of global music elements, that is, the result of hybridization. In other words, K-pop is not Korean music but global music because cannot locate its own "Koreanness" (Lie 360).

American sociologist, John Lie, who retraces the process of development of Korean music, argues that "as a matter of traditional culture, there is almost nothing 'Korean' about K-pop. K-pop, however identified as part of Brand of (South) Korea, is a globally competitive product without encumbrance of traditional Korea" (360). Japanese scholar Iwabuchi, who studied the cultural exchange phenomenon in Asia, said that the local culture accepts a global element of culture, and erases its color and creates a product called an "odorless culture." He implied that the global success of Korean cultural contents is also based on "statelessness." Shim Doo-bo (27) accepted Krady's definition of cultural hybridity as "communicative practice constitutive of, and constituted by, sociopolitical and economic arrangement" and emphasized that K-pop is a new mixed music genre of global music in Korea's new political, economic and cultural environment. Another Hallyu scholar, Oh, also emphasized how Hallyu includes K-pop as "[n]ot the globalization of Korean culture, but the Koreanization of world culture" (132).

Table 1: Cultural Contents Acceptance Model of Edward H. Spicer

\begin{tabular}{ll} 
Cultural Contents & Meaning \\
\hline Incorporative integration & $\begin{array}{l}\text { Incorporated into the request of inmates, is carried out the } \\
\text { formation of a new integration }\end{array}$ \\
Assimilative integration & $\begin{array}{l}\text { Traditional culture integrated with foreign culture and } \\
\text { assimilated into the new culture }\end{array}$ \\
Isolated integration & $\begin{array}{l}\text { Two cultures forming integration with each culture } \\
\text { isolated }\end{array}$ \\
Fusional integration & Two cultures integrated into an ideal third form \\
\hline
\end{tabular}


While humbly accepting scholarly opinions that K-pop is a global music of a new nature born in the flow of transnational culture, this research is a response to the already extant doubt that K-pop was formed in the physical place of Korea, and that Korean elements remain in it. Edward H. Spicer, an anthropologist, describes the process of accepting cultural contents that a domestic culture integrates with other cultures as a stage of incorporation, assimilation, isolation, and fusion. The acceptance process here can be understood as a pre-fusion process in which the two cultures are integrated into the ideal third form. Cultural convergence goes through the process of examining the possibility of unity with the existing culture through the stage of acceptance of culture, and identifies the possibility of another fusing in this process.

The theories of Spicer show that the acceptance and integration of culture take place in the mutual exchange of two cultures. And it shows that the process of integration with tradition must also go through the process. In other words, during cultural integration, or during cultural hybridity, traditional elements will not disappear but will mature in an idealized form. Tradition is not something made stale or worn over time, but matures during the years.

While acknowledging the academic views of K-pop as a hybrid culture without Koreanness, these views are generally addressed to the modern era, and therefore, lack a diachronic perspective. From this, we try to approach K-pop with a slightly more macro perspective. In this process, we try to examine the influence of Korean taste and tradition in K-pop.

\section{Diachronic perspective: from tradition of gwangdae to K-pop}

This study considers Korea's original gwangdae tradition as a special phenomenon peculiar to Korea, and looks at the characteristics of K-pop from the diachronic perspective of connecting gwangdae culture with K-pop.

The first feature of K-pop linked to gwangdae culture is the expert cultivation system. Although many K-pop researchers criticize the factory-produced idol group system of large-scale entertainment companies in Korea, it is undeniable that Korean K-pop promoters have an extraordinary ability in training experts at dancing and singing. This is evidenced by the fact that the foreign music market is benchmarking Korean management strategies, and that more and more volunteers (even foreign participants) are auditioning in Korean companies. This is connected to the internal arts and crafts training system that the traditional gwangdae group had. The traditional gwangdaes, who have a shared interest in artistic activity, form 
a group among themselves, and then the cultural and artistic talent transfer is made within the group, and in this process, the commonly known family tradition and heritage are completed. A closer look at the development of Korean gwangdae culture based on the diachronic viewpoint reveals that the gwangdae groups were maintained and descended under cultural or ideological factors based on the customs and values within the gwangdae organization. These customs and values of gwangdae culture, which can be called "credible commitment" (Oh et al. 100), allowed the formation of an environment in which the gwangdaes' talents and capabilities could be more specialized and upgraded. Oh's work mentions that the producers and managers of the company are doing their best to find trainees, to educate them, and to produce music. The trainees have devoted themselves to the practice of dancing and singing. This "credible commitment" occurred easily in Korea, which explains how K-pop successfully developed.

The opportunity to grow performers through competition can be regarded as the second commonality between the gwangdae culture and K-pop. K-pop performers have already experienced intense competition in the process of learning and practicing dancing, singing, and foreign language from the trainee days. In this environment, they have the opportunity for self-development, and furthermore, it also affects their skill improvement. Thus, Japanese consumers who used to criticize K-pop idols as nothing more than a just variation of J-pop idols now admit that K-pop idols' singing and dancing skills are superior to those of Japan (G. Lee, 180-181). With regard to the traditional gwangdae, as since $18^{\text {th }}$ century the number of gwangdae has increased and the gwangdae class system was maintained for 500 years in the Joseon Dynasty, Joseon Korea had a very large number of gwangdae. But these gwangdae did not have any choice to take another job and had to cultivate only entertaining skills as a gwangdae in this strict hierarchical order in which social status was passed on from parent to child. Over the $18^{\text {th }}$ and $19^{\text {th }}$ centuries, as the gwangdae culture and its contents became popular culture, the competition between gwangdae families or between gwangdae groups heightened, and they tried to demonstrate a higher level of artistic skills than others (Seo 167). In this circumstance, the gwangdaes' personal performance or their groups' abilities progressed. The second feature of K-pop linked to clown culture is found in the inherent characteristic of expert system mentioned earlier.

The third common feature is pungja and haehak which are roughly equivalent to western satire and humor (refer to part 3 for a more exact explanation about these terms). Some researchers claim that K-pop embodies the beauty of pungja and haehak, two particularities embedded in the gwangdae culture. According to them, the lyrics of some K-pop music portray Korea's particular social environment from a critical angle, adopting satirical aesthetics (SW. Lee). Psy's "Gangnam Style," which caused enormous repercussions in the world, can be cited as a typical example 
showing this. Just as the traditional gwangdae solved criticism and complaints about the class society with pungja and haehak, K-pop performers also expressed criticism of society with silly lyrics and comical gestures (Adamson 46).

The fourth common feature that connects gwangdae with K-pop is simply the Korean language. Culture critic Russell says that K-pop's Korean lyrics is the most revealing part of Korean culture. According to him, "Korean is a snappy, popping language, full of densely packed, tight syllables" and "in many ways, it is already halfway to hip-hop." He explains that using the melody in Korean means making a song that reflects the characteristics of Korean, so the song, K-pop, can only be implanted in Korean (23). Gyu-tag Lee, a scholar specialized in K-pop, explain also that how "Korean lyrics" give a strong sense of Koreanness (99).

\section{GWANGDAE AND THE GWANGDAE SPIRIT}

What is a gwangdae, the core concept of this study, and what is the gwangdae spirit? According to various studies on gwangdae culture, gwangdae groups formed after the middle of the Goryeo Dynasty (Son and Lee 177-79; Seo 62). From the mid-Goryeo Dynasty to the Joseon Dynasty, the gwangdae refers to individual performers and even professional players who were commissioned by the court to officially perform a play (Chung 143-145; Yoon 573-575). In other words, the gwangdae, in the hereditary status system, was a concept that encompasses an official artist group that participated in the events of the court while contributing to developing sophisticated folk show skills, and a popular artist group that cultivated folk shows which could be enjoyed together with the general public, like a shaman or an itinerant performers troupe. This means that the gwangdae refers to a wide spectrum of artist-performers (Sim and Kim 125).

To better understand the meaning of Korean gwangdae more clearly, it can be compared with the concept of the "fool" or the "clown," which had a similar social role and status to the gwangdae. For example, the fool, who would frequently appear in Shakespeare's plays, came from the "jester," a popular cultural form in the Middle Ages. These jesters were performers of various dances, songs, acrobatics, and obscenity in various parts of the town hall, which was held in the town square. Many jesters at that time were physically handicapped people, and they would use their physical disability as a factor to create humor (Wiles). After some time, these jesters became personal entertainers, or fools, who lived in the royal palace and provided pleasure and laughter to their masters, a King or an aristocrat. Though these fools were low in status, they had the privilege to speak and act freely and were free to seek freedom from punishment or regulation. That is, they had the right to 
satirize their employers, the King and nobility, or to make criticisms directly or indirectly (Campbelle and Goldsmiths 6). On the other hand, "clown" is a term that began to be used in the Elizabethan period to refer to a professional entertainer. If the term fool refers to those who improvise naturally, without finesse, clown is a concept that refers to a trained actor with professional acting skills, mainly on stage (Gurr). These clowns reproduced satire of the social aspects of class with ridiculous or stupid words. Korea's gwangdae is also said to have been in the lowest caste segment in terms of social status and has a common point with the fool or the clown in terms of providing comfort to the King, nobility, and the people. But it is said that the gwangdae in fact demands more expertise in the art compared with the fool or the clown. That is, the fool and the clown have the strong aspects of a player with humor, while the gwangdae has a strong aspect of a performer, presenting various shows with different professional and technical skills.

The folk shows performed by these gwangdaes needed very specialized artistic skills which were not easy to be imitated or passed down by ordinary people. This involved singing, performing pansori (epic storytelling through song), dancing, taltchum (performing mask dances), playing instruments, pungmul (folk percussion band music), puppet plays, gokye (acrobatics), jultagi (performance on a tightrope) and engaging in witty humorous chattering (YG. Lee 370). Considering that performance culture and popular play culture had absolutely relied only on the artistic expertise of these gwangdae groups especially since the Joseon Dynasty after the Goryeo Dynasty, it is not too much to say that important parts of Korean traditional folk shows have been mostly invented, handed down, and developed by the gwangdae groups.

The gwangdae groups usually maintained their organization and culture in the national system involving a hereditary status structure until the mid-Joseon Dynasty. Since the $18^{\text {th }}$ century, however, they started to show a relatively big change in their size and activities: as the increased agricultural productivity of Joseon society since the $18^{\text {th }}$ century led to commercial and market development and the court official events, Narye, were no longer held after Jeongjo of Joseon (1752-180o), the 22nd ruler of the Joseon Dynasty, ${ }^{5}$ the activities of the gwangdae groups developed in more various ways (Chung 111-151). With the advancement of marketplaces and seasonal fish markets at the port, the gwangdae groups often performed folk shows in such open spaces in which many ordinary people gathered. Supported and bolstered by the public's empathy with and preference for folk shows, these gwangdaes' activities quantitatively flourished to form a kind of popular performance culture in Joseon society (Yoon 705-710). Since then, the gwangdae groups attempted to develop a new system so that they could create and sell their own unique entertainment in this competitive market system. Thus, the popular gwangdae system (which was born spontaneously beyond the hereditary 
status system) had a great ripple effect not only on the public but on society and cultural arts. A major example of the successful popular gwangdae system is a male troupe of itinerant entertainers, called namsadang, who appeared in the late Joseon Dynasty. It was a gwangdae troupe that was active in the important transition period in which the gwangdae system changed from being nation-centered to public-centered (Chung 145-151).

The Korean gwangdae culture system, which underwent a change with the abolition of the hereditary status system at the end of the $19^{\text {th }}$ century, evolved in the course of various cultural phenomena related to the Enlightenment, the Japanese colonial period, the US military government period, and the period following the establishment of the Republic of Korea. As a result, modern styles of theatrical performance emerged; groups of musicians were formed by record companies; and music performance culture flourished centering on the musical troupes of the eighth US military units stationed in Korea. The traditional gwangdae were absorbed by these modern entertainment groups. Indeed, the gwangdae groups and their culture went through numerous changes in such situations and it is still believed that the gwangdae spirit remains and has its influence in harmony with foreign culture. From the 1960s to the 1980s, many new features were introduced into Korean popular music, including a fusion of overseas pop music and Korean traditional melodies, and the acceptance of overseas pop music into Korean popular music. The 1990 os was a time when the Korean gwangdae spirit underwent innovative changes in form and content. A new generation of gwangdae with a new sense of the times was beginning to emerge. With the advent of "SeoTaiji and Boys," who displayed new kind of song and dance skills, various musical genres were combined such as hip-hop and a unique yet popular type of music was performed. This was an epoch-making event that alerted many people to the importance of management in the popular music-producing market. Since then, the entertainment agencies have developed a comprehensive management specific to Korea that manages a wide range of items including record planning and production, entertainer management, star marketing and even music distribution. Furthermore, these comprehensive entertainment companies came to establish even a system to discover and train competitive new gwangdae. Under the steady and systematic management of these companies, Korean popular music with its cultural code has achieved constant changes and innovations, thus developing as K-pop, a successful form of cultural content (JH. Yang 138).

In fact, the passing down of the Korean gwangdae culture and spirit to today's K-pop after a long development process is closely connected to the Korean people's cultural tendency of enjoying music and dancing. In other words, it can be interpreted that the Korean people's cultural particularity, which can be characterized by heung and sinmyeong or pungja and haehak, constantly stimulated and developed the 
Korean gwangdaes' temperament and capability, thus contributing to cultivating and enhancing Korean music and performance skills (Joo et al.; M. Kim et al.). ${ }^{6}$ Heung refers to an "elevated and positive emotional state such as impression and pleasure," and leads to singing and dancing as the degree of excitement becomes higher. Sinmyeong means entering a powerful ecstatic state and immersion while feeling intense joy and enthusiasm, which releases conflicts and contradictions between humans and then uplifts the emotional mood (S Lee 215-218). Pungja and haehak are not different in caricaturing targets to cause laughter. However, pungja induces a cold, cynical smile for the purpose of criticizing and exposing the hypocrisy of the targets, while haehak evokes a soft empathetic laughter out of compassion for the targets (SW. Lee 205). In particular, Korean pungja and haehak not only produce laughter by lampooning targets, but also embrace them and bring harmony. In this regard, they are different from Western satire and humor, which are sharp and direct (K. Shin 190-191). This study suggests that such a traditional gwangdae spirit remains in modern K-pop. Another important factor related to the passing down of the deeply embedded gwangdae spirit to K-pop is that the succession and development of cultural arts through the gwangdae have taken place at a diachronic level. In other words, the cultural and artistic capabilities of Korean gwangdae groups were constantly accumulated and strengthened under the influence of institutional elements and several foreign cultures. This study applies the diachronic perspectives in analyzing the gwangdae system and cultural hybridity theory is used in observing the transmission of the gwangdae spirit.

\section{THE DEVELOPMENT OF THE GWANGDAE SPIRIT AND THE SUCCESSION TO K-POP}

In this part, based on the diachronic viewpoint suggested above, the development of the gwangdae culture and system will be closely examined, in order to understand how Korea's gwangdae particularities have been handed down to today's K-pop.

\section{The Development of the Gwangdae System in the Joseon Dynasty}

Gwangdae, as already stated above, refers to a group of professional entertainers who had engaged only in entertaining and performing activities since the Goryeo Dynasty, based on a hereditary social status system. They pursued popularity and artistry at the same time while singing, playing musical instruments, dancing, performing puppet plays, doing gokye (acrobatics), jultagi (performance on a tightrope) and engaging in witty and humorous banter (Hee-chul Sim and Hun-shik 
Kim 208). In the Joseon Dynasty, performers from hereditary shaman groups, gisaengs who are female entertainer-courtesans, jaeseung, talented monks who engaged in performing activities (J. Park 152-53) and itinerant performance troupes such as sadang were working as gwangdaes. In the late Joseon period, especially the itinerant gwangdae troupes were engaged in active and diverse entertaining activities. During this period, the gwangdae culture was extended to the middle class and even the common people, and female performers also became involved in such activities (Chung 139-149; Yoon 705-710). The gwangdae groups, who used to be mobilized for official government events, travelled to flourishing commercial areas such as marketplaces to act as private performance troupes because in this period official government events were no longer held. They devised perfect performance while regularly performing folk shows in villages and markets, which were different from one-time ceremonial events. As their performances unfolded at private banquets, held not by the government offices but by individuals, the witty, humorous banter evolved into pansori, a kind of folk play. Indeed, the energetic activities and various compositions of private performance troupes and their large size enabled music and dance and even folk plays to develop and evolve. Another itinerant gwangdae groups known as namsadang was formed by farmers with a high level of entertaining skills who had lost farmland due to famine or natural disasters, and this kind of group was characterized by spontaneous formation among common people (W. Shim 25).

\section{The Succession of Gwangdae Culture in Modern and Contemporary Times}

In the modern era, the hereditary social status system was abolished along with the Kabo Reform of 1894. Under the influence of enlightenment thinking, modernstyle theaters appeared. As for the traditional music performances, such as pansori, miscellaneous songs or folk songs, and gwangdae shows which were held in villages and marketplaces, the stage for them was moved to modern theaters. Indeed, the composite art performances composed of court and popular music and dance were put on the stage, which contributed to the widened range of classes who enjoyed popular culture by breaking down the boundary between high culture and low culture. In addition, as foreign culture was introduced and accompanying interest in entertainment and play culture increased, new types of performances developed in a way to accommodate foreign elements. Along with the introduction of foreign music, domestic music also went through various changes of genre. At this time, gisaengs displayed outstanding talent in the field of music as singers. At the beginning of the 2oth century, these giseangs formed a union, a so-called gisaeng johap, as a base of their activities, and thereafter, many other singers and musicians partook in various musical exchanges and carried out many performances centering 
around this union. This gisaeng johap, which would be entitled gwonbon soon by the Japanese government, was a kind of expert cultivation center where giseangs learned and polished music and dance skills (Hwang 12-13). These gisaengs acted not only as singers of popular songs but also as main players of a new theatrical performance genre, further growing as artists and stage performers. As gisaengs who were good at traditional performance and had well developed entertaining skills embraced both traditional song styles and diverse foreign music styles, a mix of music styles coexisted. The record companies and the music industry which appeared at the same time led popular music, mixed with existing traditional songs, such as pansori or minyo (folk songs), Japanese song today referred to as enka ${ }^{7}$ and Western music that was introduced in modern times, to become the axis of culture.

As akgeuk, a form of musical drama that combined drama with music, was developed from the 1940s, numerous musical drama troupes, called akgeukdan, were formed. Since the 1950 s when the US army was stationed in South Korea, the singers belonging to these troupes visited the US military bases to perform musical shows. After the mid-1950s, akgeuk was transformed into variety shows and akgeukdan became showdan, or a troupe of show. These showdans at first performed musical activities such as performances for the US army, and then gradually extended the scope of activities to the "general stage" for Korean audiences. ${ }^{8}$ After the mid-1960s, it became common for Korean musicians to perform musical shows on the general stage as well as on the "show stage" for the eighth US army. They played American jazz, blues, and pop, but they also even made and sang Americanstyle Korean songs for Korean fans. In this way, the Korean gwangdaes at that time continued their activities based on a kind of cultural system, rooted in stage performance, following the theater performance of the Japanese imperialism era. In this stage system, singers and musicians of showdan formed a kind of training union and polished their music and performance skill as they competed with many other groups. In the 1970s, these musicians who had originally performed for the US army were at the center of the domestic music industry, thanks to the record industry as well as radio and television, which had been developed since the 1960s, and the British and American music that they introduced to Korea had an effect on the formation of Korea's distinctive pop culture (H. Shin 135-142). ${ }^{9}$ However, as the authoritarian government of 1960s-70s tightened the regulation on the cultural sphere (SW. Lee 82), including the musical environment, musicians of this period tended to perform and train their musical skill underground. In the 1980s, actively led by talented Korean musicians, a variety of foreign musical genres, such as folk, rock, soul, ballad, dance music, and trot (Japanese-style popular music), were combined with Korean traditional music, contributing to the establishment of the Korean popular song style (G. Lee 76). The efforts and activities of talented Korean gwangdaes led to the formation of contemporary popular music with a Korean identity (Jang and Seo 264-288, 320-338). In this period, the activities and culture of 
these Korean musicians grew and developed in a solid bond with the broadcasting system, especially through the television system, and musicians began to compete with their colleagues to appear more in the television stage.

\section{The Development of the K-Pop Gwangdae System}

It is no exaggeration to say that the development of K-pop, which started in the late $1990{ }^{10}{ }^{10}$ is a cultural phenomenon generated by the power of popular songs in the 1990s, especially the accumulation and propagation of the gwangdae spirit and capabilities of "SeoTaiji and Boys." In 1992, "SeoTaiji and Boys" came to sudden prominence in the Korean popular music industry by performing creative and experimental songs that combined rap, traditional Korean music and dance music with rock. The group gained explosive popularity and support from many teenagers with their new innovative songs in combination with hip-hop and dance, and thus clearly showed the possibility of successfully commercializing idol groups based on dance in the then music market. Indeed, the group's appearance was followed by the idol group-oriented commercialization phenomenon in the Korean popular music industry. Since the mid-199os, idol groups including the H.O.T. and Sechskies who were first generation of K-pop, have been competitively formed.

Moreover, the advent of "SeoTaiji and Boys" shook the Korean popular music market in another way. Until the 1980s, popular music singers belonged to record companies. They engaged in entertainment activities that included releasing record albums under an exclusive contract with record companies. However, SeoTaiji quickly broke with the custom of the existing popular music market by producing and recording an album as well as writing and composing songs on his own. He also even engaged in casting, training, and marketing all alone (SW. Lee 165). Under the influence of the example of "SeoTaiji and Boys," album producing and entertainment management started to become separated in the 1990s. A full-scale corporate management agency was introduced in Korea's popular music industry with the establishment of SM Entertainment (SM). Modeled after "Motown," the US record company, and "Johnny's," Japan's large entertainment agency, SM adopted a "total management" strategy in which it would not only produce, promote, distribute and market music, but also operate a "system to produce idol singers" by picking a small number of would-be singers, training them for a long time and helping them make their debut. In this way, the expert cultivation tradition turned up again in Korean society. Following SM, other entertainment agencies, such as YG or JYP (which became a large company), also adopted this total management strategy, transforming it to fit Korea's social and cultural context (G. Lee 120-124). 
These large management agencies, which are leading K-pop at the forefront of global popular culture, have produced a new type of K-pop performers through this elaborate and keen competitive system, referred to as the "idol training system," including the trainee system. ${ }^{11}$ The gwangdae groups in the traditional era developed and inherited their capacity as gwangdae within their group. And the gwangdaes after the modern age, although they were also based on several modern cultural and industrial institutions such as the stage system, record system, and broadcast system, mostly achieved the accumulation, strengthening, and transmission of their talents and capabilities within their group itself. And we can find this competitive expert cultivation system which is Korean gwangdae's culture, in these entertainment agencies' training system. Now, the gwangdae training system is institutionalized, and through this elaborate system, the artistic values and temperament of gwangdaes was systematically accumulated and transmitted. The establishment of this system contributed greatly to today's rising global boom of K-pop.

Then, how has the content of K-pop, led by a gwangdae system that has been changed into a competitive institution operated by large entertainment agencies, inherited the traditional gwangdae spirit? In recent years, there have been studies scientifically demonstrating that K-pop has inherited musical or aesthetic elements of Korean traditional music. Some researchers pay attention to the "hook song," one of the main musical characteristics of K-pop. Emphasizing that the fast and repetitive tempo is related to the dance-inducing heung, they maintain that K-pop has inherited the characteristic of folk songs that repeats a simple musical structure emphasizing rhythm (SW. Lee 136). Other researchers claim that K-pop embodies the beauty of pungja and haehak, which works off the frustration that is rooted in various forms of social oppression. According to them, the lyrics of some K-pop music, such as the songs of H.O.T. or Sechskies or Psy, portray Korea's social environment from a critical angle, adopting satirical aesthetics. In other words, gwangdaes are more clown or jester-like: "they don't have to be sexy idols to be popular. Their songs are either very humorous, or can sound serious, but with silly lyrics" (Adamson 46). The original gwangdae were given a certain amount of license to critique the aristocracy, offering up satirical commentary on society through their dance, music, and repartee. This idea supposes a place for Psy in the cultural history of the Korean people by showing a precedent in which the jester, standing outside and powerless himself, might speak truth to power by means of sarcastic jokes and parody. We can insist that a tradition from pre-modern times such as this were still active in modern Korea like the case of Psy (Adamson 46).

The following table outlines the Hybridity process of the Korean gwangdae culture into the K-pop system. 
Table 2: Long-term Hybridity Process: from Gwangdae culture to K-pop

\begin{tabular}{|c|c|c|c|}
\hline & $\begin{array}{l}\text { Development } \\
\text { of Gwangdae's Expert } \\
\text { System }\end{array}$ & $\begin{array}{l}\text { Diffusion } \\
\text { of Modernization }\end{array}$ & $\begin{array}{l}\text { New Process of } \\
\text { Hypermodernity }\end{array}$ \\
\hline $\begin{array}{l}\text { Pre-modern } \\
\text { Times }\end{array}$ & $\begin{array}{l}\text { - Development of } \\
\text { the skill and artistry } \\
\text { in singing pansori, } \\
\text { dancing, taltchum, } \\
\text { playing instruments, } \\
\text { pungmul, puppet plays, } \\
\text { gokye, jultagi and witty } \\
\text { humorous chattering, } \\
\text { etc } \\
\text { (After the Mid Joseon } \\
\text { Dynasty Period) } \\
\text { - Social expansion of the } \\
\text { gwangdaes'sphere of } \\
\text { activity } \\
\text { - The skills of } \\
\text { gwangdae were } \\
\text { developed through the } \\
\text { competition system } \\
\text { between gwangdae } \\
\text { groups } \\
\text { - More popular and } \\
\text { creative performances } \\
\text { were created, focusing } \\
\text { in particular on } \\
\text { itinerant gwangdae } \\
\text { groups with great } \\
\text { popularity }\end{array}$ & $\begin{array}{l}\text { The growing popularity } \\
\text { of gwangdae } \\
\text { performances } \\
\text {-Spread of folk } \\
\text { performances to the } \\
\text { public } \\
\text {-Social spread of } \\
\text { troupes of itinerant } \\
\text { male entertainers, } \\
\text { called namsadang }\end{array}$ & $\begin{array}{l}\text { (After the Mid Joseon } \\
\text { Dynasty Period) } \\
\\
\text { - There were increasing } \\
\text { original performances } \\
\text { including pungja and } \\
\text { haehak targeting the } \\
\text { general public. }\end{array}$ \\
\hline
\end{tabular}




\begin{tabular}{|c|c|c|c|}
\hline $\begin{array}{l}\text { Modern to } \\
\text { Contemporary } \\
\text { Times }\end{array}$ & $\begin{array}{l}\text { Gwangdae culture } \\
\text { remains within a } \\
\text { sociocultural system } \\
\text { instead of a national } \\
\text { system. } \\
\text { - Japanese Colonial } \\
\text { Period: } \\
\text { E.g. Gwonbon (which } \\
\text { was originally Gisaeng } \\
\text { Johab) } \\
\text { - 1950s -1980s: } \\
\text { Capabilities as } \\
\text { gwangdae were } \\
\text { exchanged and } \\
\text { strengthened under } \\
\text { the cultural system } \\
\text { including the US army's } \\
\text { show stages, the music } \\
\text { listening room as the } \\
\text { source of youth culture } \\
\text { and TV showcases. } \\
\text { - 1990s: } \\
\text { Broadcast system, } \\
\text { record industry system, } \\
\text { management system } \\
\text { "SeoTaiji and Boys" } \\
\text { became a model for } \\
\text { Korea's systematic } \\
\text { idol training system } \\
\text { centering on dance and } \\
\text { singing. }\end{array}$ & $\begin{array}{l}\text { Social spread of } \\
\text { Korean pop music } \\
\text { combined with British } \\
\text { and American styles } \\
\text { by musicians from US } \\
\text { army stages and youth } \\
\text { culture }\end{array}$ & $\begin{array}{l}\text { 1950s to 1980s: } \\
\text { - Emergence of } \\
\text { performance group } \\
\text { with a new sensation, } \\
\text { consisting of musicians } \\
\text { from the eighth US } \\
\text { army stage and youth } \\
\text { culture, inspired by } \\
\text { British and American } \\
\text { music. } \\
\text { - Through the } \\
\text { remarkable activities } \\
\text { of these musicians and } \\
\text { the next generation } \\
\text { of musicians who } \\
\text { were influenced by } \\
\text { them, various musical } \\
\text { genres were combined } \\
\text { to create Korean pop } \\
\text { music. } \\
\text { After the late 1980s: } \\
\text { - A lot of dance music } \\
\text { and singers appeared. } \\
\text { 1990s: } \\
\text {-The appearance of } \\
\text { "SeoTaiji and Boys" } \\
\text { contributed greatly } \\
\text { to the strengthening } \\
\text { and development of } \\
\text { capabilities and talents } \\
\text { of Korean entertainers. }\end{array}$ \\
\hline $\begin{array}{l}\text { Since the } \\
2000 \mathrm{~s}\end{array}$ & $\begin{array}{l}\text { - The establishment of } \\
\text { the total management } \\
\text { system and "idol } \\
\text { training system," } \\
\text { centering on large } \\
\text { entertainment agencies. } \\
\\
\text { - Through the "trainee } \\
\text { system" within large } \\
\text { entertainment agencies, } \\
\text { the skills and capacity } \\
\text { of young Korean } \\
\text { entertainers for dance } \\
\text { and singing have been } \\
\text { strengthened. }\end{array}$ & $\begin{array}{l}\text { The global spread of } \\
\text { K-pop culture through } \\
\text { SNS }\end{array}$ & $\begin{array}{l}\text { - The heung / sinmyeong } \\
\text { and pungja / haehak, } \\
\text { referred to as } \\
\text { gwangdae culture } \\
\text { element, remain in } \\
\text { K-pop music and dance. }\end{array}$ \\
\hline
\end{tabular}




\section{K-POP STRATEGIES BASED ON THE GWANGDAE SPIRIT}

As seen above, Korean traditional K-pop, as the inheritor of a long-extant traditional practice, developed into current K-pop by going through various changes and innovations to meet the demands of the times and the market. In this section, the ways to sustain and enhance the competitiveness of K-pop are explored in terms of the study's theoretical perspectives, and further the examination of the culture hybridity theory of K-pop. The direction of a gwangdae strategy will also be examined.

\section{From Gwangdae to K-pop: between Tradition and Cultural Hybridity}

The K-pop strategies based on the gwangdae spirit can be summarized as outlined below, based on the viewpoint of the study's theories laid out above.

First, in deriving the K-pop strategies based on the gwangdae spirit, the approach needs to be addressed from a diachronic angle. Today's K-pop has been handed down from the traditional gwangdae culture through family tradition, private educational relationships, and the socio-cultural environment. In this paper, the characteristics of K-pop are considered on a chronological basis based on the characteristics of the gwangdae spirit. Moreover, special genre-based contents such as the expert training system, introduction of a competitive system through audition and self-growth opportunities, and the combination of satire against the class culture and masks, are most conspicuous. Moreover, the tradition of a dynamic culture based on the characteristics of cultural language called "Korean" is related on the diachronic level.

Second, it is necessary to fully consider the feature of cultural hybridity in order to understand the K-pop phenomenon. A closer look at the cultural hybridity factors as a K-pop new gwangdae strategy reveals that a popular trend can be expanded and reproduced by establishing and spreading a star system from the outside. Spatially, it is possible to know that related main functions concentrate in specific areas where cultural exchanges with overseas countries are active. Trends propagate in a relatively short time through broadcasting mechanisms; under circumstances where mass culture has been centralized in Seoul, the center of the economy and culture, and the three major broadcasters and relevant entertainment management systems have been concentrated in Yeouido, Seoul. This can be defined as a massproduction strategy from the cultural industry tradition from the west for the new K-pop system that has combined with the advanced and diversified IT environment 
such as social media, connected to the image-making and promotional strategy of stars, which then combines to make everything about stars a trend.

Third, considering an industrial brand strategy that takes advantage of the gwangdae system and spirit according to the trends and changes of the times. According to the strategy of industrial change and brand, the gwangdaes and the gwangdae system have been established as differentiated cultural characteristics by going through various innovations and cultivations to be inherited and developed as today's new gwangdae brand. The gwangdae capabilities of individuals and of the times are seen not only as forms of excellence of the times but have the potential to be inherited and developed by the next generation as acquired individual, cultural and social characteristics such as epigenetic inheritance. Excellent cultural and artistic talents form a family tradition and heritage and lead to the reproduction and development of a musical temperament through repetitive training and performance. This is well explained in the gwangdae system, the star quality of the gwangdae, the franchise strategy of star contents, and the trans-media strategy. Therefore, the brand building of stars and contents formed by gwangdaes and the gwangdae system over a long time can be defined as the new industrial brand strategy, meaning that the capacity of an acquired new gwangdae culture gene continues to be expanded and creates new added-values.

The difference between the K-pop strategies based on the gwangdae spirit and existing or traditional one is that the former emphasizes the institutionalization of the training system and the transmission of the capabilities accumulated through such a system. In other words, the K-pop strategies based on the gwangdae spirit regards the role of the training system as important and demands that the trainingrelated functions led by educational institutions and the entertainment agencies are further strengthened in terms of system. Thus, K-pop strategies based on the gwangdae system aims to build a system that is participated in by government departments, educational institutions, and field staff. In educational institutions, knowledge and capabilities necessary for the K-pop scene can be cultivated; national policy can be aimed at the example of the US "triple-helix" system, where policies needed by educational institutions and management companies are mapped out and supported. 


\section{K-pop Strategy Orientation based on the Gwangdae Spirit}

Based on the previous argument, the direction of a K-pop strategy related to the gwangdae is summarized into a model as follows. The following model shows the direction for reference by various stakeholders in formulating strategy based on the understanding of the gwangdae spirit.

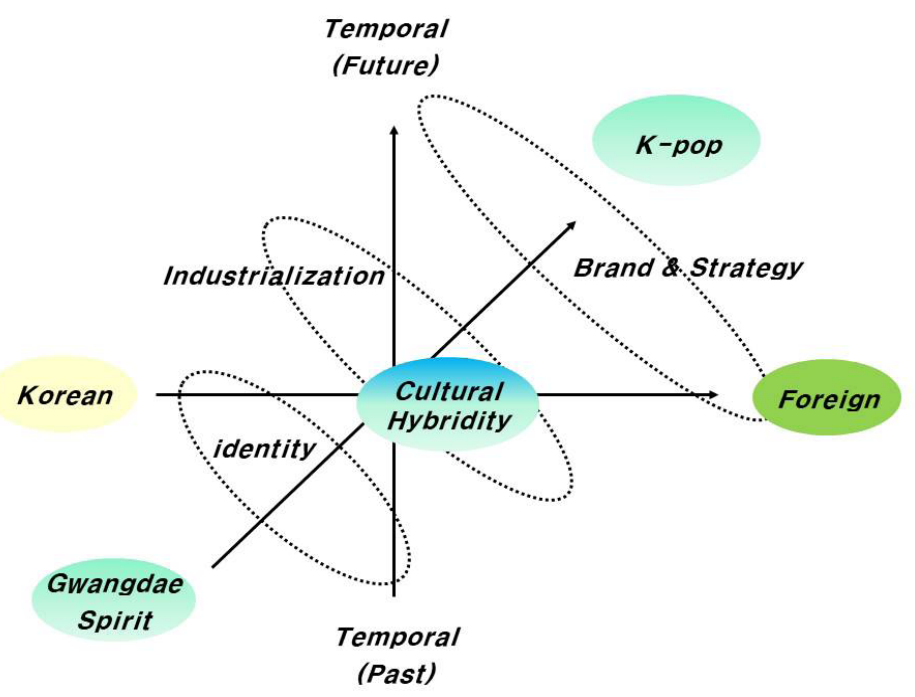

Fig. 1: The contemporary K-pop gwangdae strategy orientation (model)

First of all, from a temporal point of view, diachronic factors are considered related to tradition along the flow of time from the past to the future. In this way, considering the flow of time is an attempt to confirm that the gwangdae spirit is meaningful from a time-based point of view. The institution and spirit of gwangdae do not remain as a simple historical relic, but its traces are still extant in K-pop through changes and applications to various content. In terms of cultural hybridity, traditional Korean elements show the possibility of developing into new cultures, making contact with foreign cultures.

This trend reflects the spatial characteristics and is based on the fact that K-pop reflects the characteristics of a super-national culture. But, as mentioned earlier, for it was formed in the specific, physical location of South Korea, the characteristics from Korean traditional elements can encounter foreign cultures and develop evolutionarily. Step by step, these features will be able to recognize even to the 
stage of strategy development where the identity of one country develops into a cultural industry and develops into a representative some kind of brand. A brand culture approach offers perspectives on how brand actors co-create, circulate, and re-configure existing meanings of brands and cultures, and how traditional brands become vehicles for meaning co-creation across national boundaries (Schroeder, Borgerson and $\mathrm{Wu}$ ). Some Chinese cases showed how the selective definition of historical and traditional cultural resources, in conjunction with global systems, had the potential to transform a local and regional brand into a global brand (Zhiyan, Borgerson and Schroeder).

Through these stages, it is judged that the cultural value of the Korean gwangdae can be generated by the universal phenomenon called K-pop.

\section{CONCLUSION}

The recent rise of K-pop has led to greater social and academic attention regarding the origins and history of K-pop. Accordingly, this study, focusing on the connection between the gwangdae culture and K-pop, examined what kinds of changes and innovation Korean popular culture has undergone, living up to the demands of the times, from ancient times to contemporary times.

This research viewed the modernization of the traditional gwangdae system as a continuous stream of creation from a macroscopic viewpoint, and assumed that creative energy based on the musical competitiveness of traditional music of previous periods could be the starting point of the Korean pop music legacy in the 21st century's K-pop period to establish a "Korean style" cultural identity. As mentioned above, tradition is not something made stale or worn over time, but matured during the years without losing its original meaning

The context in which the gwangdae culture developed to K-pop and the process of hybridization from traditional gwangdae culture to contemporary K-pop were addressed through a diachronic perspective. Through this analysis, it can be concluded that traditional gwangdae culture has been established as Korean-style cultural contents while going through various innovations and changes to meet the demands of the market based on periodical changes, cultural needs, and the public preferences. The upgrading of entertaining skills through transformation and recreation and the accumulation of capabilities of gwangdae culture through the spread and reproduction of popular culture eventually may be leading to the rise of today's K-pop culture. Through these arguments, some current cases of K-pop and K-pop strategies based on the gwangdae system were discussed. In other words, the 
new gwangdae spirit and system are linked to the success factors of contemporary K-pop. Of course, in this process, the influence of foreign cultures has had a lot of influence when considered through the theoretical lens of cultural hybridity. Now, Korea needs a more strategic and elaborate policy for the K-pop industry and the new gwangdaes' role in the cultural phenomenon that is meaningful to understanding the idea and role of cultural hybridity. Surely, we believe that further discussion will follow this paper. Through the discussion of this paper, we are looking at the strategic implications that subsequent research should consider in relation to K-pop in the future. Beyond the current K-pop system, in order to develop future K-pop strategies based on the gwangdae system, it is necessary to pursue a strategy of creativity, propagation, transmission, and accumulation through the understanding of the international cultural exchange system, the old tradition and heritages preserved by the government and corporations, the advancement and innovation of the system of K-pop entertainment agencies, and the K-pop digital convergence strategy.

This study suggests that the gwangdae spirit should influence the viewpoints of the government, state, corporations and management, universities and educational institutions. Of course, many discussions and further research are necessary for this suggestion and to ensure the legitimacy of tradition and K-pop's relationships internationally. More effort and research are required for analyzing and measuring the actual, real-world manifestations of this paper's theoretical models. Accordingly, future research should match the support system from the perspective of collaboration between industry, academia, and other institutions because it will require a huge budget and many human resources. This is important in that the study can lead to national policy-oriented innovation related to a new economic model and realization of educational value, rather than contributing only to cultural and artistic traditions. Above all, K-pop based on tradition and philosophy can bolster the arguments of cultural hybridity and understanding professionals such as the gwangdae. In that sense, it is necessary to carry out a comprehensive and continuous study with the collaboration of industry, academia, and other institutions based on the coexistence of various academic viewpoints, instead of a partial study based on a narrow range of experiences. 


\section{Acknowledgement}

This work was supported by the National Research Foundation of Korea Grant funded by the Korean Government (2014S1A3A2044638).

\section{Notes}

1. This branch of research is being led mostly by the Advanced Center for Korean Studies. Notably, scholars who consider K-pop as a trans-national phenomenon have taken a very critical attitude towards this perspective (see G. Lee 159-161).

2. As we consider that gwangdaes, Korean traditional entertainers-performers, have unique characteristics that differ from those of the fool or clown in the European tradition, we have retained this Korean word without translating it.

3. Although gwangdae can be traced back to even before the Goryeo Dynasty period, this paper found its origin in the Goryeo Dynasty period, considering that gwangdae refers to a group socially defined by the caste system, part of the national system, and a folk art group formally mobilized for official events. Many scholars mention that the term "gwangdae" began to appear in the literature since Goryeo Dynasty and thus, they judge groups of gwangdae to have been established since that period (Chung 143-145; Seo \& Kim 201-202; Yoon 573-582). However, as the entertainers who played the role of gwangdae existed before the Goryeo Dynasty and some scholars consider that gwangdae groups have originated in performers migrating from China or Manchuria in Silla period before the Goryeo Dynasty, the origin of gwangdae may be discussed from various angles and viewpoints.

4. Originally this definition is from Rowe and Schelling's literature, Memory and Modernity: Popular culture in Latin America.

5. Narye, court official events, was abolished in 1634 under Injo of Joseon (1595 $-1649)$, the $16^{\text {th }}$ ruler of the Joseon dynasty, and after Sukjong (1661-1720), the $19^{\text {th }}$ ruler, it began again but was held intermittently. Then it disappeared officially in Jeongjo (Chung 111-112).

6. This study attempts to partially accept the cultural genetic theory already stated in the introduction. The heung and sinmyeong, and pungja and haehak are referred to as Korea's distinctive gwangdae spirit in this study, on the basis of the surveys related to Koreans' cultural genes, carried out by the Advanced Center for Korean Studies in 2012 and 2013, and the studies based on them. According to the 2012 survey by the Advanced Center for Korean Studies, the 1o selected Korean cultural genes were harmony/concordance, heung/sinmyeong, courtesy, composure, dynamics, naturalness, community, han (a deep-rooted melancholic pain), fermentation, and patience/tenacity. In the "2013 survey of Korean cultural genes 
by generation and age," in addition, harmony/concordance, heung/sinmyeong, emotional bond/love, passion/challenging spirit, and community culture were selected as the essential elements of the Korean cultural genes that have lasted for more than 50 years (Joo et al.; Kim et al.). Researchers in this field, while they have acknowledged that the Korean cultural genes have had significant effects on the global success of the Korean wave and K-pop, stress that more academic studies and scientific analysis are needed to raise the persuasive power of the theory because it is not yet complete (C. Park 30-33). More recently, the Korean cultural genetic theory is laying a more solid foundation as there are studies emerging that scientifically demonstrate the claim that K-pop has inherited the musical and aesthetic elements of Korean traditional music such as heung and haehak (refer to SW. Lee).

7. Enka were Japanese appropriations of Western harmony (Young-mee Lee 7).

8. Most of scholars or experts on Korean popular music says the eighth US military's show stages played a huge role in deep connection between Korean popular music and Western pop (refer to H. Shin, Y. Lee and SW. Lee).

9. Korean pop music researchers emphasize the great effect of the "music listening room" on the spread of British and American pop in Korea at that time. Since the end of the 196os, foreign pop songs had been spread and consumed around cultural spaces such as the "music listening room." As such public spaces became part of the cultural institution within Korean society, they contributed to producing new young musicians who made and sang the songs in which Korean lyrics were combined with "American-style" genres including soul, rock and folk. Soon, known as singers from "youth culture," they came to acquire the status of pop stars, with their performances broadcast in showcase programs on $\mathrm{TV}$, the major mass media of the day, along with the singers from the US army performance stage (H. Shin 142-159).

10. Most popular music critics and researchers believe that a K-pop boom originated in the late 1990s, when the first-generation idols, particularly H.O.T., began to actively engage in overseas activities (SW. Lee 59; H. Shin 45; JY. Yang 23).

11. The trainee system operated by large entertainment agencies is one of the key elements in the system used by the current agencies to churn out teenage idols, which sets Korean management agencies far apart from the foreign ones mentioned above in terms of their system. The trainee system in Korea has so many unique factors that it is even nicknamed the "Korean-style idol training system." In particular, the trainees, mostly as teenagers, have to go through years of intensive training in dance and singing, be regularly assessed by their agency in terms of their capabilities and skills, and undergo thorough privacy management and control for image-making (G. Lee 120-124). 


\section{Works Cited}

Adamson, R. M. “There is No Such Thing as Gangnam Style: And Why Psy's Summer Hit Might Even Be Good." Groove Korea Magazine, October 2012, Issue 72, pp. 42-48.

Campbell, O. J. and R. H. Goldsmith. Wise Fools in Shakespeare. Michigan State UP, 1995.

Chung, Hyeong-Ho. Hankuk Jeontong Yeonhuiui jeonseunggwa miuishik [Transmission and Aesthetic of Korean Traditional Performances]. Minsokwon, 2008.

Gurr, Andrew. The Shakespearean Stage, 1574-1642. Cambridge UP, 1992.

Hwang, Mi-yeon. Gwonbongwa Giseanguro bon sikminji geundaesung [Gwonbon, Gisaeng and Modernity in the Japanese colonial period]. Minsokwon, 2013.

Iwabuchi, Koichi. Asialul Innun daejung munhwa [Recentering Globalization: Popular culture and Japanese Transnationalism]. To Hanaui Munhwa, 2004.

Joo Young-Ha et al. Hankukinui munhwa yujeonja [Koreans' Cultural DNA]. Amor Mundi, 2012.

Kim Moon-kyum et al. Hankukinui ilsanggwa munhwa yujeonja [Everyday Life and Cultural DNA of the Korean], Story House, 2014.

Kim, Pyung-soo. "Eungdaphara! 1990 nyeondaeui cheongnyeon munhwa" [Reply! Youth Culture of 199o's]. Hankukinui ilsanggwa munhwa yujeonja [Everyday Life and Cultural DNA of the Korean], edited by Korean Studies Advancement Center, Story House, 2014, pp. 138-223.

Kraidy, Marwan M. "Hybridity in Cultural Globalization." Communication Theory, vol. 12, no. 3, 2002, pp. 316-339.

-.. Hybridity, or the Cultural Logic of Globalization. Temple UP, 2005.

Lee, Gyu-tag. K-pop sidae [The K-pop age: from cassette tape to streaming]. Hanul M Plus, 2016.

Lee, Sang-min. "K-pop, segyeinui maeumye 'heung'ul doduda" [K-pop spreads the heung all over the world]. Hankukinui munhwa yujeonja [Koreans' Cultural DNA], edited by Korean Studies Advancement Center, Amor Mundi, 2012, pp. 212-29.

Lee, Sang-wook. K-pop yeongu [K-Pop studies]. Interbooks, 2016.

Lee, Young-geum. "Jeontong munhwaui woncheonuroseoui mu munhwaui galaewa uisang: Honam jiyuk seseupmu jipdanul jungshimuro" [Branches of Korean Shamanism Culture and Its Status as a Source of Traditional Culture: with Focus on Troupes of Hereditary Shaman in Honam Area]. Asian Comparative Folklore Society, vol. 44, 2011, pp. 351-95.

Lee, Young-mee. “The Beginning of Korean Pop: Popular Music during the Japanese Occupation Era (1910-45)." Korean Pop Music: Riding the Wave, edited by Keith Howard, Global Oriental, 2006.

Lie, John. "What is the K in K-pop? South Korean Popular Music, the Culture Industry, and National Identity." Korea Observer, vol. 43, no. 3, 2012, pp. 339-363.

-.. Hankuk daejung gayosa [History of Korean Popular Song]. Minsokwon, 2006.

Oh, Ingyu. "Hallyu hyunsangul wae hakmunjeokeuro yeonguhanun gushi jungyohanga?" Philosophy and Reality, vol. 110, Sept. 2016, pp. 127-150. 
--. and Gil-Sung Park. "From $\mathrm{B}_{2} \mathrm{C}$ to $\mathrm{B}_{2} \mathrm{~B}$ : Selling Korean Pop Music in the Age of New Social Media." Korea Observer, vol. 43, no. 3, 2012, pp. 365-397.

--. et al. Hallyu 3.ogwa munhwa glocalhwaui inmunhakjeok yeongu [Humanistic analysis of Hallyu 3.0 cultural glocalization]. National Research Council for Economics, Humanities and Social Sciences, 2014.

Park, Chi-wan. "Jinan 50 nyeongan hankukinui munhwa yujeonja, muoty oteoge bakuiotneunga" [Koreans' Cultural DNA in the past 50 years, what changed?]. Hankukinui ilsanggwa munhwa yujeonja [Everyday Life and Cultural DNA of the Korean], edited by Korean Studies Advancement Center, Story House, 2014, pp. 16-46.

Park, Jeon-Yol. "Joseon sidae yurang yeinui geytonggwa yeonhui" [The system and the performance of wandering clown]. Civil lecture of Korean History, vol. 45, 2009, pp. 151-70.

Pieterse, J. N., "Globalization as Hybridization." Global Modernities, edited by M. Featherstone, S. Lash, and R. Robertson, Sage, 1995.

Rowe, W. and V. Schelling. Memory and Modernity: Popular Culture in Latin America. Verso, 1991.

Russell, M. J., K-POP Now! The Korean Music Revolution. Tuttle, 2014.

Schroeder, J., J. Borgerson, and Z.J. Wu. "A Brand Culture Approach to Chinese Cultural Heritage Brands." Journal of Brand Management, vol. 22, no. 3, 2015, pp. 261-279.

Seo, Yeon-ho. Hankuk gongyeonyesului wonriwa yeoksa [The Principle and History of Korean Performing Arts]. Worin Publishing, 2011.

Seo, Yeon-ho and Kim, Hyun-chul. Hankuk yonhuiui wonriwa bangbob [The Method and Principle of Korean Performance]. Worin Publishing, 2006.

Shim, Doo-bo. "Hybridity and the rise of Korean popular culture in Asia." Media, Culture E Society, vol. 28, no. 1, 2006, pp. 25-44.

Shim, Woo-sung. Tal [Mask], Daewonsa, 1994.

Shin, Hyun-joon. Gayo, K-pop geurigo geu neomeo: hankuk daejung eumakeul yknun munhwajeok prism [Gayo, K-pop and beyond. Cultural prism for understanding of the Korean popular music], Dolbegae, 2007.

Shin, Kwang-chul. "Jayouwa haebangul wechin cheongnyoenui sidae: 1980 nyeondae jeohanggwa bipanui jeongshin [Era of Youth: spirit of resistance and criticism of 1980's]. Hankukinui ilsanggwa munhwa yujeonja [Everyday Life and Cultural DNA of the Korean], edited by Korean Studies Advancement Center, Story house, 2014, pp. 116-36.

Sim, Hee-chul and Kim Hun-shik. K-popui jeonshingwa systmeui giwon [The Origin of K-Pop's spirits and system]. Pyungmisa, 2015.

Son, Tae-do and Ja-gyun Lee. "Gwangdae jipdane daehan yeongu II: Gyeonggi ibuk jaeinchongwa gwandae [Study of gwangdae group II: Gwangdae village and gwangdaes in north of Gyeonggido]. Study of Classical Play, vol. 2, 2001, pp. 177-219.

Son, Tae-do. "Segye yesulsaeseo saerowoon yesul segyelul yeon pansori" [The Pansori: as a world art]. Pansori Journal, vol. 14, 2002, pp. 199-225.

Spicer, Edward H. Cycles of Conquest: the Impact of Spain, Mexico and the United States on the Indians of the Southwest 1533-1960. The University of Arizona Press, 1962. 
Straubhaar, Joseph D. "Beyond media imperialism: Asymmetrical interdependence and cultural proximity." Critical Studies in Mass Communication, vol. 8, 1991, pp. 39-59.

Yang, Jae-young. "K-popui glocal jyeonryakgwa honjong jeongtcheseong: post-Hallyu sidae K-popui sahoemunhwajeok jihyunge daehan sogo" ["Glocal” strategies and hybridity of K-Pop: the sociocultural landscape of K-Pop in the age of post-Hallyu]. The Journal of Music Application Studies, vol. 4, 2011, pp. 19-37.

Yang, Jong-Hoe. "The Korean Wave (Hallyu) in East Asia: A Comparison of Chinese, Japanese and Taiwanese Audiences Who Watch Korean TV Dramas." Development and Society, vol. 41, no. 1, June 2012, pp. 103-147.

Yoon, Kwang-bong. Hankuk yeonhui yesulsa: yusahan Jungkuk.Ilbonui yeonhuilulsalpymyeo [The Art History of Korean Performance: comparing with Chinese and Japanese Performance]. Minsokwon, 2016.

Wiles, David. Shakespeare's Clown: Actor and Text in the Elizabethan Playhouse. Cambridge UP, 1987.

Zhiyan, W., J. Borgerson, and J. Schroeder. From Chinese Brand Culture to Global Brands: Insights from Aesthetics, History and Fashion. Palgrave Macmillan. 2013. 